\title{
ARTLKKELT
}

Tiina Saari \& Harri Melin

\section{Työn voimavarat ja organisaatioon sitoutuminen suomalaisyritysten yksiköissä Suomessa ja Venäjällä}

\begin{abstract}
Abstrakti
Tässä artikkelissa vertaillaan organisaatiositoutumista ja sen taustatekijöitä kahden suomalaisyrityksen Suomessa ja Venäjällä toimivissa yksiköissä. Artikkelin tutkimuskysymys on, kummassa maassa työntekijät ovat sitoutuneempia organisaatioonsa ja ovatko suomalaisten ja venäläisten työntekijöiden organisaatiositoutumiseen yhteydessä erilaiset työn voimavarat. Analyysimenetelminä on käytetty ristiintaulukointia, varianssianalyysiä ja logistista regressioanalyysiä. Tutkimuksen tulosten mukaan Venäjällä sijaitsevien yksiköiden työntekijät ovat kummassakin organisaatiossa sitoutuneempia kuin Suomessa sijaitsevien yksiköiden työntekijät. Regressioanalyysin perusteella sekä Suomessa että Venäjällä työntekijöiden organisaatiositoutumiseen olivat yhteydessä työyhteisön tuki sekä kehittymismahdollisuudet työssä. Suomalaisten työntekijöiden sitoutumista vahvistavat lisäksi mahdollisuudet vaikuttaa työhön. Tyytyväisyydellä johtamiseen tai palkkaan ei sen sijaan ollut kummassakaan maassa tilastollisesti merkitsevää yhteyttä organisaatiositoutumiseen.
\end{abstract}

Johdanto

Venäjä on suomalaisille yrityksille tärkeä markkina-alue, ja monilla suomalaisilla yrityksillä on Venäjällä myös merkittäviä tuotantolaitoksia ja muuta liiketoimintaa. Vuonna 2016 Venäjä oli viennissä Suomen viidenneksi tärkein ja tuonnissa toiseksi tärkein kumppani. Venäjällä toimii yli 500 suomalaista yritystä, jotka työllistävät lähemmäs 50000 paikallista työntekijää (Suomalais-venäläinen kauppakamari 2018; Elinkeinoelämän keskusliitto 2018). Kun suomalainen yritys toimii Venäjällä, yhdistyy arjen käytännöissä kaksi erilaista työkulttuuria. Millaiselta siis näyttää työhyvinvointi, kun verrataan suomalaisen organisaation Suomessa ja Venäjällä toimivia yksiköitä? Tässä artikkelissa vertaillaan työn voimavaroja ja organisaatio- sitoutumista kahden suomalaisomisteisen organisaation suomalaisissa ja venäläisissä yksiköissä. Lisäksi selvitetään, mitkä työn voimavarat ovat positiivisessa yhteydessä affektiiviseen organisaatiositoutumiseen. Tutkimuksen teoreettisina lähtökohtina toimivat työn voimavarojen ja vaatimusten malli (Demerouti, Bakker, Nachreiner \& Schaufeli 2001) sekä kolmijakoinen sitoutumisen malli (Meyer \& Allen 1991).

Tutkimus kohdistuu yksityiseen sektoriin, joka on Venäjällä uudistanut rakenteitaan ja toimintatapojaan huomattavasti rohkeammin kuin valtion omistamat yritykset ja julkinen hallinto. Venäläisen yksityisen sektorin työkulttuuri ja esimerkiksi johtamistavat ovat jo hyvin lähellä länsimaisia (esim. Balabanova, Efendiev, Ehrnrooth \& Koveshnikov 2015). Yksityiseen sektoriin keskittyvien tutkimus- 
ten tuloksia ei kuitenkaan voi yleistää kuvaamaan koko Venäjän työelämää, jossa kokonaisuudessaan löytyy yhä vahvoja kaikuja sosialismin aikaisista tavoista ja käytännöistä (esim. Puffer \& McCarthy 2011). Esimerkiksi autoritääriset johtamistavat ja paternalistinen suhtautuminen työntekijöihin ovat peräisin sosialistiselta ajalta, mutta ne ovat edelleen osa venäläistä työelämää. Näitä ja muita Venäjän työelämälle tyypillisiä käytäntöjä käsitellään tässä artikkelissa myöhemmin.

Venäjällä työntekijöiden sitouttaminen on haastavaa, koska työpaikkaliikkuvuus on ollut poikkeuksellisen nopeaa sekä 1990-luvulla että 2000-luvulla (Gimpelson \& Lippoldt 1999; Tan ym. 2007). Myös alhainen työttömyys ja pula koulutetusta työvoimasta lisää kilpailua työntekijöistä. Lisäksi osaavat tekijät vaihtavat työpaikkaa nopeasti esimerkiksi palkan perässä, etenkin suurissa kaupungeissa. (Kapeliushnikov \& Oschepkov 2014; ks. Balabanova, Efendiev, Ehrnrooth \& Koveshnikov 2016; Karhunen, Kosonen, Logrén \& Ovaska 2008, 198.) Ulkomaiset yritykset pyrkivät pärjäämään tässä kilpailussa työntekijöistä sitouttamalla työntekijänsä, esimerkiksi tarjoamalla hyvät sosiaaliset edut ja keskimääräistä paremman palkkauksen (Kozina 2010). Vastaavasti Suomessa työpaikkaliikkuvuus on selvästi vähäisempää, ja Suomen työmarkkinoilla työsuhteiden keskimääräinen pituus on tilastojen mukaan jopa pidentynyt. Tilastokeskuksen työolotutkimuksen mukaan vuonna 2013 vastaajat työskentelivät saman työnantajan alaisuudessa keskimäärin hieman yli kymmenen vuotta, kun vuonna 1984 aika oli hieman yli kahdeksan vuotta. (Sutela \& Lehto 2013, 27.)

Näistä lähtökohdista voisi arvella, että suomalaisten organisaatioiden työntekijät Venäjällä olisivat vähemmän sitoutuneita kuin saman yrityksen työntekijät Suomessa. Tutkimuskysymyksenä onkin, kummassa maassa työntekijät ovat sitoutuneempia organisaatioonsa. Artikkelissa vertaillaan sekä affektiivisen, normatiivisen että jatkuvuussitoutumisen tasoja. Toinen tutkimuskysymys on, ovatko suomalaisten ja venäläisten työntekijöiden affektiiviseen organisaatiositoutumiseen yhteydessä samat työn voimavarat. Tähän kysymykseen vastataan vertailemalla ensin suomalaisten ja venäläisten tyytyväisyyttä johtamiseen, palkkaukseen, työyhteisöltä saatuun tukeen sekä kehittymis- ja vaikuttamismahdollisuuksiin työssä. Sen jälkeen analysoidaan, ovatko nämä työn voimavarat yhteydessä affektiiviseen sitoutumiseen. Affektiivinen sitoutuminen valittiin jatkuvuussitoutumisen ja normatiivisen sitoutumisen sijaan tarkempaan analyysiin, koska affektiivinen sitoutuminen on sen sisältämän emotionaalisen työpaikkaan kiinnittymisen vuoksi merkittävin sitoutumisen tapa, joka vaikuttaa eniten työntekijän toimintaan (Mercurio 2015).

Aiemmissa vertailevissa tutkimuksissa (Saari, Melin, Balabanova \& Efendiev 2017; 2018; Saari, ym. 2017) on havaittu, että suomalaiset yksityisen sektorin työntekijät ovat venäläisiä tyytyväisempiä johtamiseen ja kokevat useammin työn imua. Tämän tutkimuksen keskiössä olevaa organisaatioon sitoutumista koskevaa vertailututkimusta ei ole aiemmin tehty Suomen ja Venäjän välillä. Tämän tutkimuksen tavoitteena on tuottaa tietoa, jota organisaatioiden johto voi hyödyntää pohdittaessa käytäntöjä, joiden avulla lisätä työntekijöiden organisaatiositoutumista sekä Suomessa että Venäjällä.

\section{Suomalaista ja venäläistä työelämää}

Venäjän markkinoilla toimii lukuisia ulkomaisia yrityksiä ja niiden tytäryhtiöitä. Joidenkin arvioiden mukaan niiden tuotanto muodostaa jopa kolmanneksen Venäjän kulutustavaroiden tuotannosta (Gurkov 2014). Kun yrityksen tytäryhtiö operoi ulkomailla, tytäryhtiössä toimitaan ainakin osittain emomaan yrityskulttuurin mukaisesti, eli emomaan toimintamalleja ja menettelytapoja siirretään myös tytäryhtiöön. Aina siirtäminen ei kuitenkaan toteudu täydellisesti. Esimerkiksi Markku Sippola (2011; 2016) on tutkinut Pohjoismaisten yritysten toi- 
mintaa Venäjällä ja Baltiassa. Hän on huomannut, että yritykset eivät suinkaan aina vie mukanaan pohjoismaisia toimintamalleja. Sippolan (emt.) mukaan yritykset eivät esimerkiksi siirtäneet työntekijöiden osallistumis- ja neuvottelumahdollisuuksia sellaisenaan. Myöskään johdon ja ammattiliittojen suhteet eivät toimi samalla tavoin tytäryhtiöiden toimintamaissa kuin emomaissa. Yleensä ammattiliitoilla on huomattavasti vähemmän valtaa ulkomaisissa tytäryhtiöissä kuin kotimaassa. Karen Newman ja Stanley Nollen (1996) ovat puolestaan esittäneet, että ylikansallisten yritysten ei tulisi viedä toimintamalleja ulkomaille sellaisenaan, vaan niiden tulisi sopeuttaa johtamistavat kunkin maan kulttuuriin ja kulttuurisiin odotuksiin mahdollisimman tuloksekkaan toiminnan saavuttamiseksi. Heidän tulostensa mukaan esimerkiksi työntekijöiden vaikutusmahdollisuuksien lisääminen sellaisissa maissa, joissa valtaerot ovat suuret, voi jopa heikentää tuloksellisuutta.

Neuvostoliiton hajoamisen jälkeisinä vuosikymmeninä yritysten rakenteet ja toimintatavat ovat muuttuneet myös Venäjällä. Venäläinen työelämä on tänä aikana lähentynyt muuta Eurooppaa. Tästä huolimatta venäläisessä yritystoiminnassa ja työelämässä on edelleen nähtävissä sosialismin aikaisia piirteitä ja käytäntöjä. Kuten sosialistisen järjestelmän aikana, Venäjän työelämää leimaavat yhä voimakas korruptoituneisuus, byrokratia, epävirallisten henkilöstöverkostojen suuri merkitys ja paternalistinen suhtautuminen työntekijöihin (Kosonen \& Parviainen 2010; Fey \& Shekshnia 2011), joita kuvaamme seuraavaksi lyhyesti.

Venäjä on hyvin korruptoitunut maa, mikä aiheuttaa Venäjällä toimiville yrityksille ylimääräisiä kustannuksia ja vaikeuttaa liiketoimintaa. Suomi taas on yksi maailman vähiten korruptoituneista maista: vuonna 2017 Suomi oli kansainvälisessä vertailussa sijalla 3 ja Venäjä sijalla 135 (Transparency International 2018). Kahden naapurimaan välillä vallitsee siis korruption suhteen valtava ero. Venäjällä rasitteena on myös maan raskas byrokratia, jonka myötä viranomaisten toimet ovat usein ennakoimattomia ja jopa mielivaltaisia. Yrityksiä ohjaavia säädöksiä muutetaan usein, ja etenkin ulkomaisten yritysten on vaikeaa sopeuttaa omaa toimintaansa uusien ohjeiden mukaisesti. (Kosonen \& Parviainen 2010.)

Venäjä on suhteiden yhteiskunta, ja hyvät suhdeverkostot ovat elintärkeitä myös yrityksille. Venäläisessä liiketoiminnassa hyödynnetään hyvin laajasti epävirallisia henkilöverkostoja sekä yritysten ja julkisen sektorin että paikallisen liike-elämän kanssa toimittaessa. Myös epäviralliset työmarkkinat ja harmaat palkat ovat yleisiä (Kosonen \& Parviainen 2010). Venäjällä toimivat suomalaisyrityksetkin tiedostavat suhdetoiminnan tärkeyden. Suhteita tarvitaan sekä viranomaisiin että muihin yrityksiin. Ilman suhteita asioiden hoitaminen on hitaampaa ja vaikeampaa. (Heininen, Mashkina, Karhunen \& Kosonen 2008; Kosonen \& Heliste 2006.) Suhdetoiminnassa tärkeä osa henkilösuhteiden toimintaa on blat eli epävirallisiin henkilösuhteisiin perustuvan vaihdon kulttuuri, jossa tehdään palveluksia odottaen, että ne myös vastavuoroisesti korvataan. (Kosonen \& Parviainen 2010; Michailova \& Worm 2003, 510.) Tutkijoiden mukaan blatin merkitys työelämän käytännöissä etenkin yksityisellä sektorilla on kuitenkin vähentymässä (Kosonen 2008; Balabanova ym. 2016).

Tämän tutkimuksen kannalta erityisen kiinnostava ja keskeinen piirre venäläisessä työelämässä on työnantajien paternalistinen suhde työntekijöihin. Neuvostoliitossa yritykset vastasivat monista Suomessa kunnille kuuluvista tehtävistä. Ne järjestivät päivähoidon, rakensivat asuntoja ja pitivät huolta myös tehdasyhdyskuntien infrastruktuurista, kuten tiestöstä. Yrityksillä oli työntekijöilleen myös omia ammattikouluja. Neuvostoliiton hajottua venäläiset yritykset luopuivat monista sosiaalisista tehtävistään. Nyt paternalistisiin menettelyihin ollaan palaamassa uudestaan (Leppänen, Linden \& Solanko 2008; Melin 1996; 2005). Työnantajat tarjoavat edelleen työntekijöilleen sosiaalisia etuja, kuten 
työpaikkaruokailun, sairasvakuutuksen sekä lastenhoitopalveluita. Tämä asetelma on säilynyt sosialismin ajoista tähän päivään, koska yritysten tarjoamat sosiaaliset palvelut ovat hyvä keino sitouttaa työntekijöitä. Myös ulkomaalaisomisteiset organisaatiot jatkavat tätä perinnettä. (Kozina 2010; Kosonen \& Parviainen 2010, 149; Gurkov 2016.) Ulkomaalaisomisteisissa yrityksissä tarjotaan yleensä myös kilpailukykyistä palkkaa ja bonuksia. Niissä panostetaan myös kehittymisja etenemismahdollisuuksien tarjoamiseen. (Gurkov 2016.)

Venäjällä yrityksillä on erityisen suuri tarve sitouttaa työntekijöitään, mutta sitouttaminen on samalla hyvin haastavaa. Haasteina ovat suuri työpaikkavaihtuvuus, kilpailu koulutetuista osaajista sekä matalan syntyvyyden ja työikäisten miesten suuren kuolleisuuden aiheuttama vähäinen työvoiman tarjonta (Karhunen ym. 2008; Bondarenko 2015). Työttömyys on Venäjällä pysytellyt matalalla tasolla, noin viidessä prosentissa, ja myös työllisyys on pysynyt korkealla (Gimpelson \& Kapeliushnikov 2011; Kapeliushnikov \& Oschepkov 2014; ks. Balabanova ym. 2016).

Ulkomaalaisomisteisissa yrityksissä on Venäjällä pyritty sitouttamaan työntekijöitä myös yhteisöllisyydellä sekä työntekijöiden ja organisaation yhteisillä eduilla, mutta kunnon palkka koetaan yhteisöllisyyttä tärkeämmäksi (Kozina 2010). Venäläisille palkansaajille ovat yleensä tärkeämpiä työn ulkoiset kuin sisäiset arvot. Palkka ja muu palkitseminen ovat siis tärkeämpiä kuin vaikkapa työn kiinnostavuus (Anikin 2011; Balabanova ym. 2016). Tässä suhteessa ero esimerkiksi Suomeen on todella merkittävä. Suomessa kiinnitetään paljon enemmän huomiota työn sisältöön ja muihin vastaaviin tekijöihin. Palkan merkitys työhön kiinnittymisessä on Suomessa laskenutjo yli 20 vuoden ajan (Sutela \& Lehto 2013, 24).

Suurten valtaerojen Venäjällä johtaminen on ollut hierarkkista ja työntekijät eivät ole juurikaan voineet osallistua muodolliseen organisaatiota koskevaan päätöksentekoon (Puffer \& McCarthy 2011; Gimpelson \& Kapeliushnikov
2011; Anikin 2011). Venäläinen johtamistapa on historiallisesti perustunut autoritääriseen ylhäältä alaspäin johtamiseen (Melin 1996). Yhteiskunnan yleisen modernisoitumisen myötä myös venäläinen johtamistapa on uudistumassa uuden sukupolven astuessa johtotehtäviin. Nuoremman sukupolven korkeasti koulutetut johtajat ovat kasvaneet sosialismin jälkeisessä ajassa ja tottuneet asioimaan myös kansainvälisten liikekumppaneiden kanssa (esim. Balabanova ym. 2015; Akindinova, Kuzminov \& Yasin 2016). Sosialistisen ajan käytännöt vallitsevat kuitenkin yhä edelleen etenkin julkisella sektorilla ja valtion omistamissa yrityksissä, jotka muodostavat ison osan taloudesta (Gurvich 2016). Venäläistä johtamistapaa onkin hankala tiivistää yhdeksi tai edes kahdeksi paradigmaksi, kuten uuteen ja vanhaan. Pikemminkin tilannetta kuvaa heterogeenisyys, eli johtamistapoja on useita (Balabanova ym. 2018). Esimerkiksi Evgeniya Balabanova, Aleksey Rebrov ja Alexei Koveshnikov (2018) jaottelivat tutkimuksessaan venäläiset yksityisen sektorin johtajat johtamistyylin mukaan neljään luokkaan: villi kapitalisti, rationalisti, passiivinen ja staattinen. Villit kapitalistit johtavat autoritääriseen tyyliin, usein tultuaan johtajiksi nuorina ja ilman johtamiskoulutusta. Rationalistit tekevät tarkkoja suunnitelmia ja panostavat kannustimien käyttöön. Passiiviset johtajat puolestaan toimivat lyhyellä tähtäimellä, ilman kannustinjärjestelmiä ja ovat hyvin etäisiä suhteessa työntekijöihin. Staattiset johtajat kaihtavat haasteita ja pyrkivät lähinnä säilyttämään yrityksen nykyisen tilanteen.

Tällä hetkellä venäläisessä työelämässä sekoittuvat siis vanhat sosialistisen ajan käytännöt ja uudet länsimaiset mallit. Kun otetaan vertailukohteeksi Suomi ja suomalainen työelämä, Venäjän erilaisuus korostuu. Suomessa, kuten muissakin Pohjoismaissa, työelämän laatu on Euroopan parhaimmistoa. Esimerkiksi työntekijöiden autonomia sekä kehittymis- ja vaikuttamismahdollisuudet ovat kansainvälisesti erittäin hyvällä tasolla (Mustosmäki 2017; Hartikainen, Anttila, Oinas 
\& Nätti 2010; Parent-Thirion, Fernández Macías \& Hurley \& Vermeylen 2007; Gallie 2003). Armi Mustosmäen (2017) mukaan Pohjoismaat eroavatkin selvästi muusta Euroopasta korkealla pysyneessä työelämän laadussa. Monessa muussa maassa Euroopassa on samaan aikaan havaittavissa myös työelämän laadun rapautumista. Suomessa eivät ole myöskään toteutuneet polarisaatioriskit, vaan ylemmissä ja alemmissa ammattiasemassa olevien väliset erot työelämän laadun mittareilla ovat päinvastoin pienentyneet viime vuosikymmeninä. Kuitenkin myös kielteisiä kehityssuuntia voidaan havaita, ja Suomessa esimerkiksi työn kiireisyys ja koettu työn epävarmuus ovat lisääntyneet.

Suomi on tutkimusten mukaan Euroopan huippua esimerkiksi työntekijöiden mahdollisuuksissa vaikuttaa työhön ja osallistua päätöksentekoon työpaikoilla sekä osallistua työnantajan tarjoamiin koulutuksiin (Eurofound 2017). Jos venäläisen johtamistavan perinteiset piirteet - autoritäärisyys ja johtajien laajat valtaoikeudet - ovat hyvin selvillä, vastaavasti suomalaista johtamista on vaikeampi luonnehtia. Hannele Seeck $(2008,284-297)$ arvioi, että suomalaisesta johtamistraditiosta ei olla tietoisia eikä suomalaista tapaa johtaa ole tunnistettu. Seeckin (emt.) mukaan kansainväliset johtamisopit ovat kyllä rantautuneet nopeasti Suomeen ja niiden käyttöönottaminen on vastannut aina kulloisenkin työelämän kehittymisasteen ongelmaan. Nyt Seeckin (emt.) mukaan työelämän ongelmana ei enää olekaan työntekijöiden sitouttaminen, vaan esimerkiksi hyvinvointijohtamisella pyritään tukemaan työntekijöiden uudistumis- ja oppimiskykyä. Suomi on siis paitsi johtamisen myös muun työhyvinvoinnin kehittämisessä hyvin erilaisessa tilanteessa ja asemassa kuin Venäjä.

\section{Organisaatiositoutuminen ja työn voimavarat}

Organisaatiositoutuminen on paljon tutkittu aihe, ja sitoutumisen teorioista käytetyin ja testatuin on John Meyerin ja Natalie Allenin (1991) kehittämä sitoutumismittari. Mittari käsittää affektiivisen, normatiivisen ja jatkuvuussitoutumisen. Affektiivinen sitoutuminen viittaa haluun tunneperäiseen sitoutumiseen ja organisaatioon identifioitumiseen sekä haluun jatkaa työtä organisaatiossa. Normatiivinen sitoutuminen puolestaan perustuu velvollisuuden tunteeseen eli organisaatiosta lähteminen rikkoisi työntekijän omia tai yhteisön normeja. Siksi työpaikassa pysymiseen on sosiaalinen paine. Jatkuvuussitoutumisen ytimessä on tarve jatkaa työtä eli organisaatiosta lähtemisen tai sen jäseneksi jäämisen hyötyjen pohtiminen. Työpaikan vaihtamiseen liittyy usein voimavaroja vaativia muutoksia ja usein työhön jääminen arvioidaankin lopulta lähtemistä helpommaksi, eli työhönsä hieman tyytymätönkin työntekijä saattaa jäädä organisaatioon. (Meyer \& Allen 1991, 78.)

Organisaatiositoutumisella on monia positiivisia vaikutuksia sekä organisaatiolle että työntekijöille. Organisaation näkökulmasta sitoutuminen on positiivisesti yhteydessä laatuun sekä negatiivisesti yhteydessä poissaoloihin, työpaikan vaihtoaikeisiin ja työpaikan vaihtamiseen (Ng \& Feldman 2014; Riketta 2002; Cohen \& Golan 2007; Meyer, Stanley, Herscovitch \& Topolnytsky 2002; Wasti 2003). Työntekijöiden näkökulmasta sitoutuminen on negatiivisesti yhteydessä stressiin ja työperhe -konfliktiin sekä positiivisessa yhteydessä esimerkiksi työuralla menestymiseen (Ng \& Feldman 2014; Meyer ym. 2002).

Sitoutumisen edellytyksiä ovat organisaatiotasolla muiden muassa työssä johtajilta saatu tuki (Meyer ym. 2002) ja vahva johtamiskulttuuri sekä ylipäätään työntekijöitä tukevaksi koettu organisaatiokulttuuri (Mauno \& Ruokolainen 2008, 161). Sitoutumisen taustalla vaikuttavat myös henkilökohtaiset ominaisuudet kuten korkea ikä (esim. Jokivuori 2002, 52) ja matala koulutus (esim. Turunen 2012). Organisaatio- ja yksilötason syiden lisäksi sitoutumiseen vaikuttavat myös kulttuuriset arvot ja toimintatavat (esim. Meyer ym. 2012). Esimerkiksi Ronald Fischer ja Angela Mansell 
(2009) havaitsivat meta-analyysissaan, että valtaeroilla ei ollut vaikutusta sitoutumiseen. Meyer tutkimusryhmineen (2012) puolestaan havaitsi, että kulttuuriset arvot selittivät suuren osan normatiivisen ja affektiivisen sitoutumisen vaihtelusta, mutta jatkuvuussitoutumiseen ne eivät vaikuttaneet. Suomen ja Venäjän välisiä vertailuja organisaatiositoutumisesta on tehty hyvin vähän. Venäjä sisältyy ylipäätään hyvin harvoin kansainvälisiin vertailututkimuksiin. Kuitenkin aiemmin mainittuun Fischerin ja Mansellin (2009) meta-analyysiin sisältyivät molemmat maat, 46 muun maan ohella.

Työn voimavarat tukevat työntekijää työssä. Työn vaatimusten ja voimavarojen mallissa vaatimukset viittaavat työn ponnistuksiin, haasteisiin ja stressitekijöihin, kun taas voimavaroilla tarkoitetaan niitä tekijöitä, jotka auttavat työntekijää työn tavoitteiden saavuttamisessa ja työn vaatimusten kestämisessä (esim. Demerouti ym. 2001; Bakker \& Demerouti 2016). Työn voimavarat ovat osa motivaatioprosessia, jossa niiden osuus on auttaa työntekijöitä toimimaan työroolissaan ja saavuttamaan työn tavoitteet (Bakker \& Demerouti 2016).

Työn vaatimukset, kuten aikapaine, emotionaaliset haasteet ja rooliristiriidat, voivat johtaa uupumiseen ja muihin terveysongelmiin (Halbesleben \& Buckley 2004). Työn voimavarat, kuten sosiaalinen tuki, palaute ja autonomia, puolestaan ovat yhteydessä motivaatioprosessiin, joka johtaa työn imuun ja organisaatioon sitoutumiseen (Demerouti ym. 2001). Myös Jari Hakasen, Wilmar Schaufelin ja Kirsi Ahosen (2008) pitkittäistutkimuksen mukaan työn voimavaroilla on sitoutumiseen positiivinen vaikutus, joka kuitenkin kulkee työn imun lisääntymisen ja burnout-oireiden vähentymisen kautta.

Tässä tutkimuksessa tarkasteltaviin työn voimavaroihin kuuluvat tyytyväisyys esimiestyöhön, koettu työyhteisön tuki sekä mahdollisuudet vaikuttaa työhön ja kehittää itseään. Näiden lisäksi tarkastellaan palkan oikeudenmukaiseksi kokemista, koska aiempien tutki- musten mukaan palkka on venäläisille työntekijöille erittäin keskeinen arvo työssä sekä yhteydessä vähäisiin työpaikan vaihtoaikeisiin (Anikin 2011; Balabanova ym. 2016). Esimiestyö, työyhteisön tuki sekä mahdollisuudet vaikuttaa työhön ja kehittää itseään ovat kaikki tärkeitä organisaatiokulttuurin osia. Organisatorisen tukiteorian (Perceived Organizational Support Theory, POS) mukaan organisaatiolta saatu tuki edistää työntekijöiden hyvinvointia. Työntekijöitä tukevassa organisaatiokulttuurissa työntekijöitä kohdellaan oikeudenmukaisesti ja arvostetaan, ja heillä on esimerkiksi mahdollisuus vaikuttaa työhönsä ja kouluttautua. (Rhoades \& Eisenberger 2002.) Saija Maunon ja Mervi Ruokolaisen $(2008,156)$ mukaan koettu organisatorinen tuki voi osaltaan tehdä organisaatioista työntekijöilleen työoloiltaan inhimillisiä työpaikkoja, mikä puolestaan edistää hyvinvointia ja myönteisiä työasenteita. Organisaation sitoutuminen heijastaa osaltaan myönteistä työasennetta, ja siksi organisatorinen tukiteoria toimii hyvänä lähtökohtana organisaatiositoutumisen vaikuttimien analysointiin.

\section{Aineisto, metodit ja mittarit}

Tutkimuksen aineistona on kahdessa suuressa suomalaisomisteisessa yrityksessä kerätty kysely. Ensimmäinen yritys on teollisuusyritys ja toinen yritys toimii palvelualalla. Molemmat yritykset ovat toimineet Venäjällä pitkään. Yrityksiä sekä niiden toimintaa ei yksilöidä tässä tarkemmin, koska ne ovat suostuneet tutkimusyhteistyöhön vain anonymisoituina. Kysely kerättiin vuosien 2016 ja 2017 aikana sekä Suomessa että Venäjällä toimivissa yksiköissä. Venäläisissä yksiköissä vain pieni osa työntekijöistä oli suomalaisia. Tarkemmat tiedot vastaajista ovat taulukossa 1. Tutkimus toteutettiin internetkyselynä, jonka alussa vastaajille kerrottiin vastausten käyttötarkoituksesta ja vastaajien henkilöyden salaamisesta. Yhteensä aineistossa on 636 vastaajaa. Kyselyn vastaus- 
Taulukko 1. Tutkimusaineisto

\begin{tabular}{|l|c|c|c|c|}
\hline & \multicolumn{2}{|c|}{ Teollisuusalan organisaatio } & \multicolumn{2}{|c|}{ Palvelualan organisaatio } \\
\hline & Suomen yksiköt & Venäjän yksiköt & Suomen yksiköt & Venäjän yksiköt \\
\hline Vastaajien keski-ikä & 47 & 33 & 38 & 32 \\
\hline Työvuosia organisaatiossa ka. & 17 & 6 & 9 & 7 \\
\hline Naisia & $52 \%$ & $51 \%$ & $67 \%$ & 7 \\
\hline Määräaikaisia & 6 & 8 & 158 & 64 \\
\hline Vastaajien määrä & 180 & 234 & $12 \%$ & $26 \%$ \\
\hline Vastausprosentti & $36 \%$ & $20 \%$ & & 6 \\
\hline
\end{tabular}

prosentit jäivät molemmissa organisaatioissa hyvin mataliksi (12-36\%), mikä vaikuttaa tulosten luotettavuuteen. Tuloksia voi kuitenkin pitää suuntaa antavina.

Organisaatiositoutumisen mittaamisessa käytettiin Meyerin ja Allenin (1991) sitoutumismittaria, jossa kysyttiin asteikolla 1-5 ( 1 = täysin samaa mieltä, 5 = täysin eri mieltä) vastauksia yhdeksään väittämään. Sitoutumismittareiden kysymykset ja niistä muodostettujen summamuuttujien saamat alphaarvot on esitelty liitetaulukossa 1 . Meyerin ja Allenin (emt.) sitoutumismittareita on hyödynnetty tutkimuksissa laajalti. Mittaria on testattu myös ei-länsimaisessa kontekstissa kuten Venäjällä, jossa se on myös todettu toimivaksi (Lovakov 2016).

Sitoutumisen taustamuuttujina tutkitaan JD-R-mallin eli työn voimavaroja ja vaatimuksia kuvaavan mallin voimavaroja (Demerouti ym. 2001). Tutkittaviin voimavaroihin kuuluvat tyytyväisyys esimiestyöhön, työyhteisön tuki, mahdollisuudet vaikuttaa työhön ja kehittää itseään sekä kokemus palkan oikeudenmukaisuudesta. JD-R-malliin poimittavat voimavarat vaihtelevat hieman tutkimuksesta toiseen. Tämän tutkimuksen muuttujat mukailevat Jari Hakasen $(2005,259)$ käyttämää mallia, jossa mukana ovat esimiestyö, työyhteisön tuki ja vaikutusmahdollisuudet sekä lisäksi tiedonkulku ja innovatiivisuus, joiden mukaanottoa tämän tutkimuksen aineisto ei mahdollistanut. Näidenkin kysymysten alkuperäiset mittarit sekä niistä muodostettujen summamuuttujien alpha-arvot on esitelty liitetaulukossa 1.

Tutkimusmetodeina käytetään ristiintaulukointia, varianssianalyysiä ja binäärilogistista regressioanalyysiä. Organisaatiositoutumisen eri muotojen varianssianalyysissä eli keskiarvovertailussa valittiin Post hoc -testiksi Bonferroni-testi, koska perusjoukossa ryhmien varianssit olivat yhtä suuria (eli f-testin arvo on > .05). Työn voimavarojen kuvailevassa analyysissä käytetään varianssianalyysin sijaan ristiintaulukointia, jonka kuviot havainnollistavat hyvin organisaatioiden ja niiden yksiköiden välisiä eroja. Regressioanalyysin malliksi valittiin logistinen regressio lineaarisen sijaan, koska logistinen regressio ei vaadi tutkittavan muuttujan normaalijakautuneisuutta (Tabahcknick \& Fidell 2001, 517). Tässä aineistossa affektiivinen sitoutuminen on Suomen osalta lähes normaalijakautunut mutta Venäjän osalta ei. Regressioanalyysissä selitetään voimakasta affektiivista organisaatiositoutumista. Tähän ryhmään kuuluvat ne vastaajat, joiden sitoutuminen on 5-portaisella Likert-asteikolla mitattuna erittäin tai melko voimakasta.

Koska analyysin organisatoriset taustamuuttujat ovat jatkuvia (tai tässä tapauksessa jatkuviksi tulkittuja Likert-asteikollisia muuttujia), on vetosuhteen (OR) sijaan tulkittava beta-kertoimia, joita ei kuitenkaan voi asettaa vetosuhteen tapaan suuruusjärjestykseen (Jokivuori \& Hietala 2007, 70; Best \& Wolf $2015,157)$. Tuloksista ei siten voi arvioida, vaikuttaako sitoutumiseen enemmän esimerkiksi työyhteisön tuki kuin kehittymismahdollisuudet, mutta se kertoo, mitkä taustamuuttujat ovat yhteydessä voimakkaaseen affektiiviseen sitoutumiseen. Analyysin muuttujien välillä ei todettu multikollineaarisuutta, joka haittaisi analyysiä. Voimakkaimmin keskenään korreloivat sekä suomalaisessa $(0,539)$ 
Taulukko 2. Ristiintaulukointi tyytyväisyydestä työn voimavaroihin Suomessa ja Venäjällä

\begin{tabular}{|c|c|c|c|c|c|}
\hline & $\begin{array}{l}\text { PALVELUT: } \\
\text { VENÄJÄ \% }\end{array}$ & $\begin{array}{l}\text { PALVELUT: } \\
\text { SUOMI \% }\end{array}$ & $\begin{array}{l}\text { TEOLLISUUS: } \\
\text { VENÄJÄ \% }\end{array}$ & $\begin{array}{l}\text { TEOLLISUUS: } \\
\text { SUOMI \% }\end{array}$ & $P=$ \\
\hline \multicolumn{6}{|l|}{ TYYTYVÄISYYS JOHTAMISEEN } \\
\hline Hyvin tai melko tyytyväinen & 74 & 66 & 73 & 44 & 0,000 \\
\hline Ei tyytyväinen eikä tyytymätön & 17 & 19 & 17 & 32 & \\
\hline Melko tai hyvin tyytymätön & 9 & 15 & 11 & 24 & \\
\hline TYÖYHTEISÖN TUKI & & & & & 0,000 \\
\hline Hyvin tai melko tyytyväinen & 86 & 77 & 76 & 59 & \\
\hline Ei tyytyväinen eikä tyytymätön & 11 & 18 & 13 & 26 & \\
\hline Melko tai hyvin tyytymätön & 4 & 5 & 11 & 15 & \\
\hline KEHITTYMISMAHDOLLISUUDET & & & & & 0,000 \\
\hline Hyvät & 53 & 37 & 43 & 22 & \\
\hline Kohtalaiset & 36 & 40 & 44 & 48 & \\
\hline Huonot & 11 & 23 & 14 & 29 & \\
\hline $\begin{array}{l}\text { MAHDOLLISUUDET VAIKUTTAA } \\
\text { TYÖHÖN }\end{array}$ & & & & & 0,403 \\
\hline Hyvin tai melko tyytyväinen & 45 & 44 & 49 & 38 & \\
\hline Ei tyytyväinen eikä tyytymätön & 48 & 44 & 44 & 53 & \\
\hline Melko tai hyvin tyytymätön & 7 & 11 & 8 & 9 & \\
\hline PALKKAUS & & & & & 0,501 \\
\hline Palkka korkeampi kuin pitäisi olla & 2 & 1 & 1 & 2 & \\
\hline Suunnilleen oikea palkka & 22 & 24 & 24 & 30 & \\
\hline Palkka matalampi kuin pitäisi olla & 76 & 75 & 76 & 68 & \\
\hline
\end{tabular}

että venäläisessä aineistossa $(0,595)$ tyytyväisyys johtamiseen ja koettu työyhteisön tuki. (Ks. korrelaatiotaulukot, liitetaulukot 2 ja 3.)

Organisaatiositoutuminen, työn voimavarat ja niiden yhteys kahdessa maassa

Seuraavaksi kuvataan ristiintaulukoinnin avulla työn voimavaroja eli tyytyväisyyttä johtamiseen ja työyhteisöltä saatuun tukeen sekä vaikutus- ja kehittämismahdollisuuksia. Sen jälkeen vertaillaan varianssianalyysin avulla sitoutumisen eri tapoja Suomessa ja Venäjällä.
Viimeisenä analysoidaan työn voimavarojen yhteyttä sitoutumiseen.

\section{Työn voimavarat}

Suomalaisten organisaatioiden venäläisissä yksiköissä työntekijät ovat tyytyväisempiä kuin suomalaisten yksiköiden työntekijät sekä johtamiseen, työyhteisöltä saamaansa tukeen, kehittymismahdollisuuksiin että vaikutusmahdollisuuksiin työssä. Suomalaisissa yksiköissä palkkausta pidettiin oikeudenmukaisempana kuin venäläisissä yksiköissä. (Taulukko 2.) Seuraavaksi käymme tulokset tarkemmin läpi. 
Tyytyväisyys johtamiseen: Johtamiseen ollaan molempien alojen venäläisissä yksiköissä tyytyväisempiä kuin suomalaisissa yksiköissä. Erot ovat tilastollisesti merkitseviä. Molempien alojen venäläisissä yksiköissä kolme neljästä on erittäin tai melko tyytyväisiä johtamiseen. Palvelualan organisaation suomalaisessa yksikössä erittäin tai melko tyytyväisiä on myös melko paljon, 66 prosenttia. Teollisuusalan suomalaisessa yksikössä erittäin tai melko tyytyväisiä on alle puolet.

Työyhteisöltä saatu tuki: Molempien organisaatioiden Venäjän yksiköissä työntekijät ovat tyytyväisempiä työyhteisöltä saamaansa tukeen kuin Suomen yksiköissä. Teollisuusorganisaation Venäjän yksikössä erittäin tai melko tyytyväisiä työyhteisöltä saamaansa tukeen on kolme neljäsosaa ja Suomen yksikössä noin kuusi kymmenestä. Palvelualan Venäjän yksikössä erittäin tai melko tyytyväisiä on lähes yhdeksän kymmenestä ja Suomenkin yksikössä kolme neljäsosaa.

Kehittymis- ja vaikutusmahdollisuudet: Molemmissa tutkittavissa organisaatioissa oli maiden välillä eroja työntekijöiden mahdollisuuksissa kehittää itseään. Erot olivat tilastollisesti merkitsevää tasoa. Teollisuusorganisaation Venäjän yksikössä neljä kymmenestä piti kehittymismahdollisuuksia hyvinä, mutta Suomen yksikön työntekijöistä samaa mieltä oli vain noin viidennes. Palvelualan organisaatiossa kehittymismahdollisuuksia piti hyvinä yli puolet Venäjän yksikön työntekijöistä ja Suomen yksikön työntekijöistä noin neljä kymmenestä.

Palveluorganisaation yksiköissä sekä Suomessa että Venäjällä hieman alle puolet koki voivansa vaikuttaa paljon tai melko paljon työhönsä. Maiden ja yksiköiden väliset erot mahdollisuuksissa vaikuttaa työhön eivät ole tilastollisesi merkitsevää tasoa. Teollisuusorganisaatiossa noin puolet Venäjän yksikön työntekijöistä koki voivansa vaikuttaa paljon tai melko paljon työhönsä, kun Suomen yksikössä samaa mieltä oli vain noin neljä kymmenestä.
Tyytyväisyys palkkaan: Tyytyväisyys, tai tämän tutkimuksen tapauksessa tyytymättömyys, palkkaan yhdistää suomalaisia ja venäläisiä työntekijöitä kummassakin tutkittavassa organisaatiossa. Vain hyvin pieni osa, 1-2 prosenttia, pitää palkkaansa korkeampana kuin pitäisi, jos verrataan muissa ammateissa maksettuihin palkkoihin. Suunnilleen oikeana palkkaansa pitää teollisuuden Suomen yksiköissä vajaa kolmannes ja noin neljännes muiden tutkittujen yksiköiden työntekijöistä. Palvelualan organisaatiossa molemmissa maissa noin kolme neljästä on sitä mieltä, että palkka on matalampi kuin pitäisi olla. Myös teollisuusorganisaation Venäjän yksikössä kolme neljästä on tätä mieltä, kun taas Suomen yksikössä tyytymättömiä on hieman vähemmän, 68 prosenttia. Valtaosa työntekijöistä on siis tyytymättömiä palkkaansa. Tulokset eivät kuitenkaan olleet tilastollisesti merkitsevää tasoa.

\section{Affektiivinen, normatiivinen ja jatkuvuussitoutuminen}

Keskiarvovertailun mukaan tunneperäinen eli affektiivinen sitoutuminen on voimakkain sitoutumisen tapa kaikissa tutkituissa yksiköissä (sitoutumistapojen hajonnat palvelu- ja teollisuusalalla kuvioissa 1. ja 2.). Affektiivinen sitoutuminen on voimakkainta palvelualan venäläisessä yksikössä, jossa keskiarvo on 4,1 (asteikolla 1-5). Teollisuusalan organisaation suomalaisessa yksikössä keskiarvo on vertailun matalin eli 3,0. Kaikissa organisaatioissa tunneperäinen sitoutuminen on siis voimakkain organisaatioon sitoutumisen tapa, mutta sen voimakkuus vaihtelee. Affektiivisen sitoutumisen kohdalla ryhmittäiset varianssit ovat yhtäsuuria $(\mathrm{P}=0,106)$ ja ryhmien välillä on tilastollisesti merkitseviä eroja $(\mathrm{F}=26.285, \mathrm{P}=000)$. Affektiivisen sitoutumisen keskiarvojen erot olivat Post hoc -testin (Bonferroni-testi) mukaan tilastollisesti merkitseviä $(\mathrm{P}=<0,05)$ kaikkien muiden ryhmien välillä paitsi verrattaessa 
teollisuusorganisaation Venäjän yksikköä palvelualan Suomen $(P=1,000)$ ja Venäjän yksiköihin $(\mathrm{P}=0,085)$.

Jatkuvuussitoutuminen, eli organisaatiosta lähtemisen tai jäämisen hyötyjä pohtiva sitoutumisen tapa, ei jakaudu yhtä voimakkaasti organisaatioiden välillä. Matalimmillaan jatkuvuussitoutumisen keskimääräinen taso on palvelualan organisaation Suomen yksikössä, jossa keskiarvo on 2,8 ja korkeimmillaan teollisuusalan organisaation venäläisessä yksikössä, jossa keskiarvo on 3,2. Jatkuvuussitoutumisen ryhmittäiset varianssit ovat yhtäsuuria $(\mathrm{P}=0,393)$ ja ryhmien välillä on tilastollisesti merkitseviä eroja $(\mathrm{F}=4.452$, $\mathrm{P}=0,004)$. Bonferroni-testin mukaan keskiarvoerot ovat tilastollisesti merkitseviä ainoastaan verrattaessa palvelualan organisaation suomalaista yksikköä ja teollisuusalan venäläistä yksikköä keskenään $(\mathrm{P}=0,004)$.

Normatiivinen eli velvollisuuden tunteeseen perustuva sitoutuminen sen sijaan vaihtelee enemmän. Matalimmillaan normatiivisen sitoutumisen keskimääräinen taso on teollisuusalan organisaation Suomen yksikössä, jossa keskiarvo on 2,2 ja korkeimmillaan palvelualan organisaation venäläisessä yksikössä, jossa keskiarvo on 3,2. Normatiivisen sitoutumisen varianssit ovat yhtäsuuria $(\mathrm{P}=0,692)$ ja ryhmien välillä on tilastollisesti merkitseviä eroja $(\mathrm{F}=28.701, \mathrm{P}=0,000)$. Keskiarvoerot olivat Bonferroni-testin mukaan tilastollisesti merkitsevää tasoa kaikissa muissa vertailuissa paitsi verrattaessa teollisuusalan suomalaista yksikköä palvelualan suomalaiseen yksikköön $(p=0,076)$ ja toisaalta verrattaessa palvelualan ja teollisuusalan venäläisiä yksiköitä keskenään ( $\mathrm{p}=1,000)$.

Kummassakin organisaatiossa löytyi eri maissa toimivien yksiköiden välillä tilastollisesti merkitsevä ero affektiivisen ja normatiivisen sitoutumisen tasoissa. Molempien organisaatioiden venäläisissä yksiköissä työskentelevät olivat sitoutuneempia kuin samojen organisaatioiden Suomen yksiköissä työskentelevät. Heikoimmin sitoutuneita olivat teol- lisuusalan suomalaisen yksikön työntekijät, joita eivät sitouta tunteet, jatkuvuus eivätkä velvollisuudet. Saman organisaation venäläisessä yksikössä affektiivinen sitoutuminen oli vertailun toiseksi voimakkainta, ja jatkuvuussitoutuminen vertailu korkeimmalla tasolla. Organisaatio koetaan siis siinä määrin hyväksi työnantajaksi, että lähtemisen kustannukset ja/tai vaiva arvioidaan korkeaksi. Tiiviimmin affektiivisesti sitoutuneita olivat palvelualan organisaation venäläisen yksikön työntekijät. Saman organisaation suomalaisen yksikön työntekijöiden sitoutumista luonnehtii myös parhaiten affektiivinen sitoutuminen, jolla on sitoutumisen lajeista korkein keskiarvo tässä yksikössä.

\section{Työn voimavarojen yhteys sitoutumiseen: regressioanalyysi}

Logistisessa regressioanalyysissä (taulukko 3) analysoidaan johtamisen, vaikutus- ja kehittymismahdollisuuksien sekä työyhteisön tuen yhteyttä affektiiviseen sitoutumiseen Suomessa ja Venäjällä. Näiden organisatoristen muuttujien lisäksi mukana on sukupuoli, ikä, organisaatio sekä työvuodet nykyisessä organisaatiossa.

Analyysin mukaan sekä suomalaisten että venäläisten työntekijöiden sitoutumiseen ovat positiivisessa yhteydessä kehittymismahdollisuudet sekä työyhteisön tuki. Suomessa myös vaikutusmahdollisuudet työhön olivat yhteydessä sitoutumiseen. Lisäksi Suomessa myös organisaatiolla on merkitystä: palveluorganisaatiossa työskentely ennakoi vahvempaa sitoutumista. Johtamisella tai palkan koetulla oikeudenmukaisuudella ei ollut tilastollisesti merkitsevää yhteyttä affektiiviseen sitoutumiseen.

Taustamuuttujista iällä, sukupuolella ja työvuosilla organisaatiossa ei ollut kummassakaan maassa tilastollisesti merkitsevää yhteyttä sitoutumiseen. 


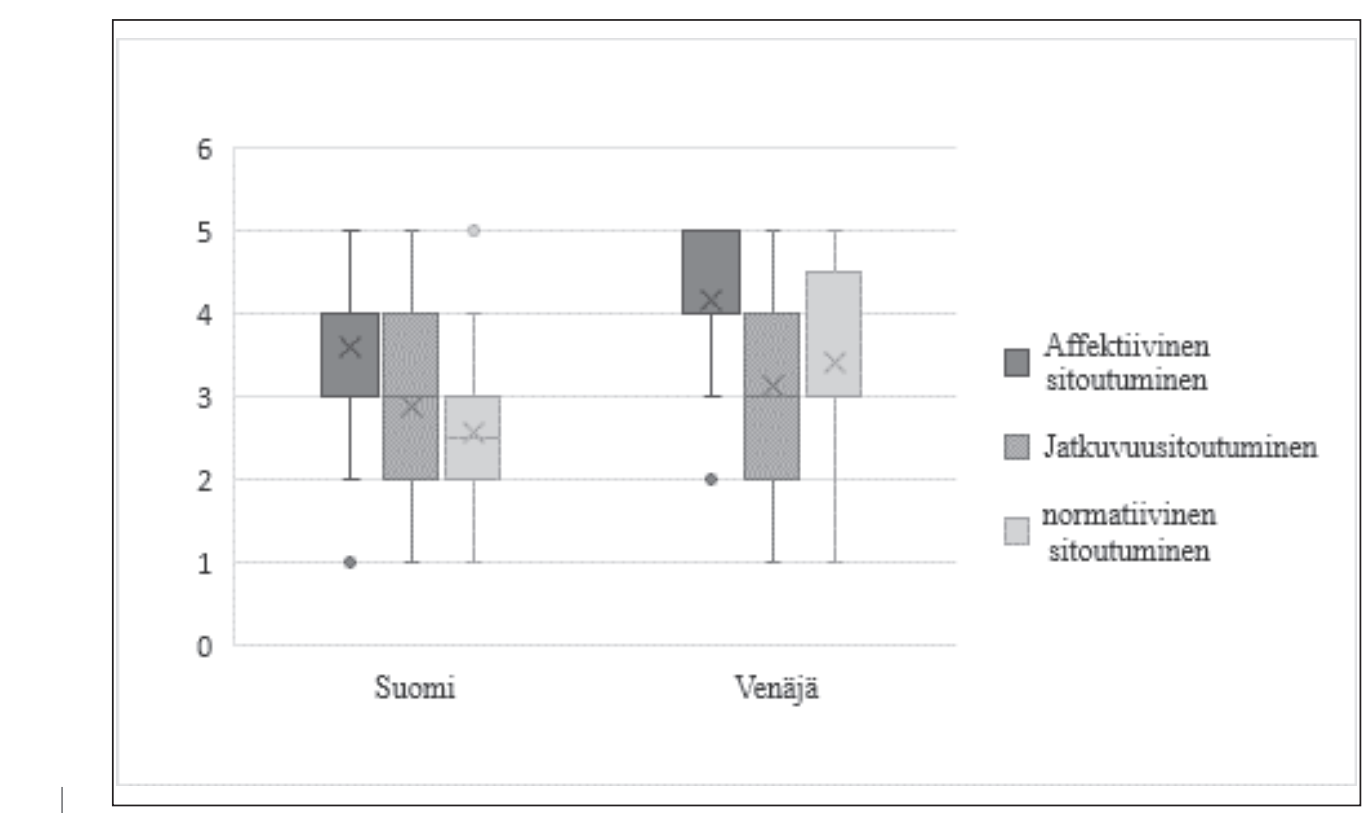

Kuvio 1. Affektiivisen, normatiivisen ja jatkuvuussitoutumisen hajonta palvelualan organisaation Suomen ja Venäjän yksiköissä

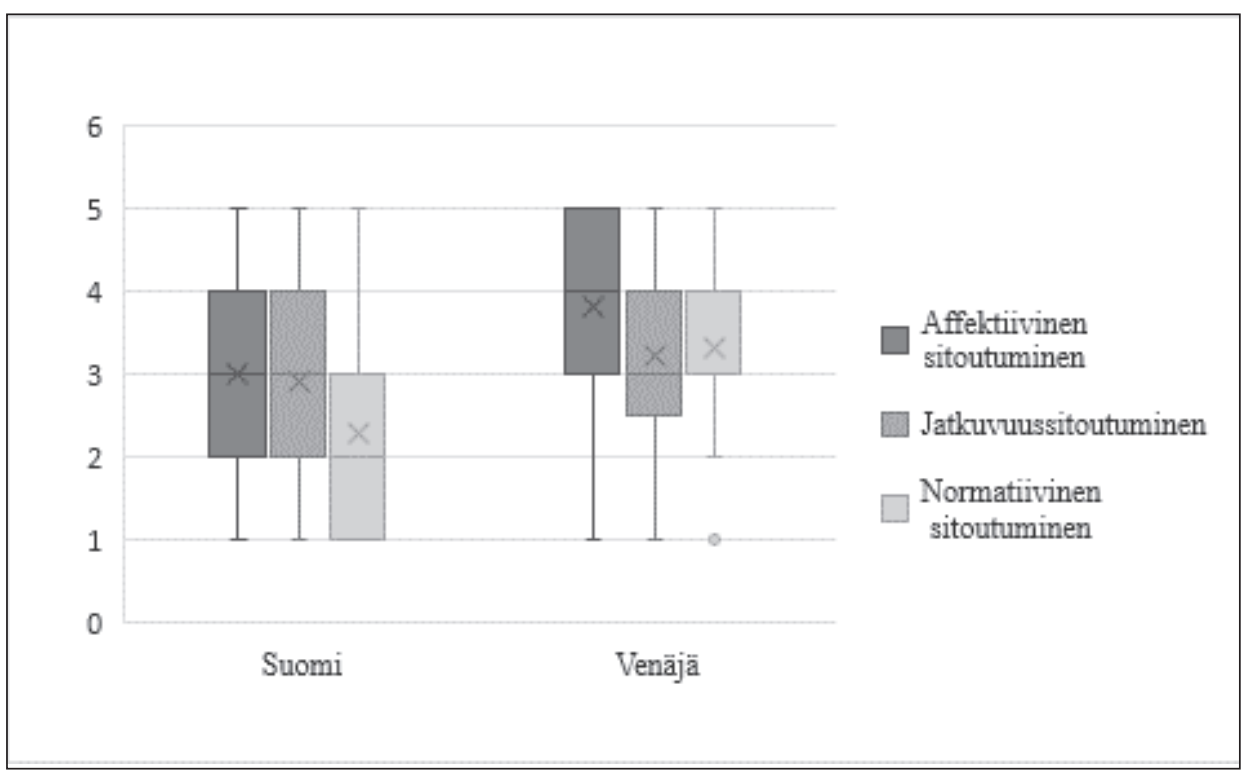

Kuvio 2. Affektiivisen, normatiivisen ja jatkuvuussitoutumisen hajonta teollisuusalan organisaation Suomen ja Venäjän yksiköissä 
Taulukko 3. Logistinen regressioanalyysi, Suomessa toimivat yksiköt. 1= korkea affektiivisen sitoutumisen taso

\begin{tabular}{|l|l|l|l|}
\hline & B & S.E. & Wald \\
\hline Johtaminen (ref. tyytymätön) & $-0,01$ & 0,15 & 0 \\
\hline Kehittymismahdollisuudet (ref. huonot) & $1,00 * * *$ & 0,23 & 18,89 \\
\hline Vaikutusmahdollisuudet (ref. huonot) & $0,40 *$ & 0,21 & 3,71 \\
\hline Työyhteisön tuki (ref. tyytymätön) & $0,62^{* * *}$ & 0,19 & 10,56 \\
\hline Palkkaus (ref. tyytymätön) & $-0,16$ & 0,19 & 0,69 \\
\hline Ikä (ref. korkea ikä) & 0,02 & 0,02 & 1,36 \\
\hline Sukupuoli (ref. nainen) & 0,25 & 0,29 & 0,74 \\
\hline Organisaatio (ref. teollisuus) & $0,98 * * *$ & 0,32 & 9,7 \\
\hline Työvuodet organisaatiossa (ref. pitkään) & $-0,02$ & 0,02 & 0,83 \\
\hline Constant & $6,68 * * *$ & 1,15 & 33,93 \\
\hline Hosmer and Lemeshow Test & 0,554 & & \\
\hline Cox \& Snell R Square & 0,267 & & \\
\hline Nagelkerke R Square & 0,359 & & \\
\hline$* * * p=0,000 * * p=<0,01 * p=<0,05$ & & & \\
\hline
\end{tabular}

Taulukko 4. Logistinen regressioanalyysi, Venäjällä toimivat yksiköt. 1= korkea affektiivisen sitoutumisen taso

\begin{tabular}{|l|l|l|l|}
\hline & B & S.E. & Wald \\
\hline Johtaminen (ref. tyytymätön) & 0,11 & 0,22 & 0,25 \\
\hline Kehittymismahdollisuudet (ref. huonot) & $0,98 * * *$ & 0,33 & 9,04 \\
\hline Vaikutusmahdollisuudet (ref. huonot) & $-0,37$ & 0,27 & 1,81 \\
\hline Työyhteisön tuki (ref. tyytymätön) & $1,39 * * *$ & 0,29 & 23,27 \\
\hline Palkkaus (ref. tyytymätön) & 0,11 & 0,28 & 0,15 \\
\hline Ikä (ref. korkea ikä) & 0,05 & 0,03 & 2,67 \\
\hline Sukupuoli (ref. nainen) & 0,31 & 0,43 & 0,53 \\
\hline Organisaatio (ref. teollisuus) & 0,2 & 0,58 & 0,12 \\
\hline Työvuodet organisaatiossa (ref. pitkään) & 0,07 & 0,05 & 1,75 \\
\hline Constant & $-8,52 * * *$ & 1,68 & 25,86 \\
\hline Hosmer and Lemeshow Test & 0,572 & & \\
\hline Cox \& Snell R Square & 0,362 & & \\
\hline Nagelkerke R Square & 0,513 & & \\
\hline$* * * p=0,000 * *$ p=<0,01 *p=<0,05 & & & \\
\hline
\end{tabular}




\section{Johtopäätökset}

Tässä artikkelissa vertailtiin suomalaisten organisaatioiden Suomessa ja Venäjällä toimivia yksiköitä sitoutumisen ja työn voimavarojen suhteen sekä analysoitiin työn voimavarojen yhteyttä sitoutumiseen. Tulosten mukaan Venäjällä toimivien yksiköiden työntekijät ovat sitoutuneempia työhönsä kuin samojen organisaatioiden Suomen yksiköissä työskentelevät. Myös organisaatioiden välillä oli eroa kaikissa työn voimavaroissa: palvelualan organisaation työntekijät olivat jokaiseen tutkittuun voimavaraan tyytyväisempiä kuin teollisuusalan työntekijät. Sekä Suomessa että Venäjällä työntekijöiden sitoutumista vahvistivat kehittymismahdollisuudet työssä sekä työyhteisön tuki. Suomalaisten sitoutumista vahvistivat myös mahdollisuudet vaikuttaa työhön.

Venäläisten yksiköiden työntekijät olivat sekä affektiivisesti sitoutuneempia että tyytyväisempiä työn voimavaratekijöihin kuin suomalaisten yksiköiden työntekijät. Johtamiseen ollaan suomalaisyritysten Venäjän yksiköissä erittäin tyytyväisiä. Tyytyväisyys voi ainakin osittain johtua siitä, että yritysten toimintakulttuuri, joka näkyy työntekijöiden arjessa parhaiten esimiestyönä, perustuu suomalaiseen johtamistapaan. Johtamisessa voi siis olla käytäntöjä, jotka ovat venäläisessä työelämässä vielä harvinaisia, kuten avoin tiedottaminen organisaation asioista.

Regressioanalyysin perusteella suomalaisten ja venäläisten työntekijöiden sitoutumiseen ovat yhteydessä samat tekijät: kehittymismahdollisuudet sekä työyhteisön tuki. Suomalaisten sitoutumiseen olivat yhteydessä myös mahdollisuudet vaikuttaa työhön. Hieman yllättävä tulos on, että johtamisella ei ollut kummassakaan maassa tilastollisesti merkitsevää yhteyttä sitoutumiseen. Molemmissa maissa sitoutumiseen liittyy siis henkilökohtainen tekijä, eli kokemus siitä, että työssä on mahdollista kehittyä (Suomessa myös vaikutusmahdollisuudet), sekä työn yhteisöllinen ulottuvuus. Tätä tulosta voisi selittää affektiivisen sitoutumisen teorian kautta, affektiivinen si- toutuminen kun kohdistuu nimenomaan organisaatioon ja työyhteisöön "perheenä". Vaikka esimiehet ovat osa tätä yhteisöä, voidaan juuri näissä tutkituissa organisaatioissa kokea tärkeämmäksi hyvät välit työtovereihin, kuten tulosten perusteella näyttäisi.

Yllättävää oli myös se, että palkan koetulla oikeudenmukaisuudella ei ollut tilastollisesti merkitsevää yhteyttä sitoutumiseen kummassakaan maassa. Useiden tutkimusten mukaan palkka on etenkin venäläisille erittäin merkittävä asia (esim. Anikin 2011; Balabanova ym. 2016) ja sen on havaittu olevan myös yhteisöllisyyttä tärkeämpi asia (Kozina 2010). Tässä tutkimuksessa yhteisöllisyys päinvastoin nousi palkkaa merkitsevämmäksi asiaksi, ainakin suhteessa sitoutumiseen.

Johdannossa todettiin, että kansainvälisesti toimivat yritykset eivät aina vie mukanaan kotimaan toimintamalleja (Sippola 2016). Johdannossa todettiin myös, että Newman ja Nollen (1996) ovat suosittaneet, että toiminta tulisi sopeuttaa kunkin maan kulttuuriin ja kulttuurisiin odotuksiin, koska esimerkiksi työntekijöiden vaikutusmahdollisuuksien lisääminen sellaisissa maissa, joissa valtaerot ovat suuret, voi jopa heikentää tuloksellisuutta. Tässä tutkimuksessa mukana olleissa organisaatioissa osa suomalaisista toimintamalleista on siirretty Venäjälle, ja myös pieni osa työntekijöistä on suomalaisia. Koska kyseessä ei ole case-tutkimus vaan työntekijöiden mielipiteisiin nojautuva, kyselyaineistoon perustuva tutkimus, käytössä ei ole tarkempaa tietoa esimerkiksi johtamismallien siirrosta Venäjälle. Tämän tutkimuksen tuloksia voidaan kuitenkin verrata aiempiin Suomen ja Venäjän työelämää koskeviin tutkimustuloksiin, joissa on havaittu venäläisten yksityisen sektorin työntekijöiden olevan useilla eri mittareilla tyytymättömämpiä työhönsä kuin suomalaisten. Venäläiset esimerkiksi kokevat vähemmän työn imua (Saari ym. 2017; 2018) ja ovat tyytymättömämpiä johtamiseen (Saari ym. 2018), kehittymismahdollisuuksiin sekä työyhteisön ilmapiiriin (Saari \& Melin 2019). Nyt käsillä olevassa tutkimuksessa tulokset 
olivat kuitenkin päinvastaisia, eli venäläiset työntekijät, tässä tapauksessa suomalaisissa organisaatiossa työskentelevät, olivat sekä sitoutuneempia että tyytyväisempiä niin johtamiseen, työyhteisöltä saamaansa tukeen, kehittymismahdollisuuksiin kuin myös vaikutusmahdollisuuksiin työssä. Yhtenä tekijänä tämän havainnon taustalla on hyvin todennäköisesti ulkomaalaisen, tässä tapauksessa suomalaisen organisaation, käytännöt, jotka poikkeavat venäläisistä työelämäkäytännöistä. Vaikka Newmanin ja Nollenin (1996) mukaan monikansallisten yhtiöiden tulisi sopeuttaa toimensa kunkin maan kulttuuriin, vaikuttaisi siltä, että ainakin tässä tutkimuksessa tarkastellut yritykset ovat tuoneet kotimaastaan mukanaan joitain hyviä käytäntöjä.

Miten sitten selittää eroa suomalaisten ja venäläisten työntekijöiden tyytyväisyydessä? Anu Järvensivu, Tatu Piirainen, Risto Nikkanen ja Elina Viitala (2011) vertailivat tutkimuksessaan työntekijöiden kokemaa työelämän laatua suomalaisen yrityksen yksiköissä Suomessa ja Puolassa. Tutkimuksen tulosten mukaan Puolan yksikön työntekijät olivat Suomen yksikön työntekijöitä tyytyväisempiä. Tutkijat pitivät tulosta yllättävänä, koska Suomen työelämän laatu on aiempien tutkimusten mukaan korkea ja Puolan vastaavasti matala. He selittivät tulosta moraalisen sopimuksen käsitteen avulla. Eri maissa odotetaan työltä näet erilaisia asioita. Puolan yksikön työntekijöille hyvä työelämän laatu oli siis jotain muuta kuin mitä se tarkoittaa suomalaisille työntekijöille (emt., 33).

Vastaavasti voisi olettaa, että venäläisillä työntekijöillä on ylipäätään matalammat työhyvinvointia koskevat odotukset. Nämä matalammat odotukset voivat selittää tyytyväisyyden tutkituissa, ainakin osittain suomalaisten standardien mukaan toimivissa työpaikoissa. Toisaalta aiempien tutkimusten mukaan ulkomaisia yrityksiä pidetään Venäjällä hyvinä työnantajina. Niiden johtaminen eroaa venäläisyrityksistä, ne maksavat yleensä parempaa palkkaa ja ne tarjoavat parempia sosiaalisia etuuksia kuin venäläiset yritykset
(Kozina 2010). Tästä näkökulmasta odotukset ulkomaista työnantajaa kohtaan voisivat olla Venäjällä myös melko korkeat, ja tästä huolimatta suomalaiseen työnantajaorganisaatioon ollaan tyytyväisiä. Lisäksi se, että samat tekijät, eli mahdollisuus kehittyä työssä ja työyhteisön tuki, olivat positiivisessa yhteydessä sitoutumiseen, kertoo suomalaisten ja venäläisten työntekijöiden saman suuntaisista odotuksista työtä kohtaan. Tässä suhteessa venäläisten työntekijöiden odotukset työelämää kohtaan lähestyvät jo länsimaisia, tässä tapauksessa suomalaisia odotuksia.

Sekä Suomessa että Venäjällä organisaatioiden on siis näiden tulosten perusteella syytä panostaa työntekijöiden hyvinvointiin, etenkin kehittymismahdollisuuksiin työssä sekä työyhteisöjen hyvään yhteishenkeen saadakseen työntekijät sitoutumaan organisaatioihin. Venäjällä on kova kilpailu osaavista työntekijöistä (Balabanova ym. 2016), joten suomalaiset ja muutkin organisaatiot voivat saada kilpailuetua tarjoamalla henkilöstölleen koulutusmahdollisuuksia ja korostamalla toimivan työyhteisön arvoa. Tutkimuksen tulokset heijastavat myös organisatorisen tukiteorian ajatusta siitä, että organisaatiolta saatu tuki edistää työntekijöiden hyvinvointia ja sitä kautta myös myönteisiä työasenteita, joihin organisaation sitoutuminenkin kuuluu (Rhoades \& Eisenberger 2002; Mauno \& Ruokolainen 2008).

Tutkimus tuotti uutta tietoa kahdessa maassa toimivien yritysten henkilöstön sitoutumisesta ja siihen vaikuttavista tekijöistä. Tutkimuksen rajoitteena on kuitenkin mainittava, että käytetty aineisto on verraten pieni ja rajoittuu vain kahteen organisaatioon. Myös matalat vastausprosentit rajoittavat tulosten yleistettävyyttä. Lisäksi on syytä pohtia, eroavatko suomalainen ja venäläinen tapa vastata kyselytutkimuksiin ja miten tämä vaikuttaa tutkimustuloksiin. Hannele Palosuon (2000) mukaan ainakin vielä 2000-luvun alkuvuosina venäläiset eivät olleet vielä niin tottuneita kyselyihin vastaajia kuin suomalaiset, mikä näkyi esimerkiksi suurena puuttuvien vastaus- 
ten määränä. Palosuo (emt.) vertaili suomalaisten ja venäläisten tapaa vastata terveyskyselyihin, ja huomasi että käsitys normaalista terveydestä oli hyvin erilainen näissä maissa. Samaan tapaan käsitys hyvästä johtamisesta tai työyhteisöstä voi saada hieman erilaisia sisältöjä maasta riippuen. Tämän aineiston perusteella ei siis voi tehdä laajoja maakohtaisia yleistyksiä. Aineistojen avulla voidaan kuitenkin esimerkinomaisesti havainnollistaa eroja maiden välillä ja ulkomaalaisomisteisten yritysten vahvaa asemaa työnantajana. Suomalaisen ja venäläisen työelämän vertailua tulisi kuitenkin jatkaa ja laajentaa, ja Venäjän tulisi osallistua kansainvälisiin vertailututkimuksiin, jotta sen työelämästä saataisiin ajantasaista ja vertailukelpoista tietoa.

\section{Kiitokset}

Kiitämme tutkimuksen rahoituksesta Työsuojelurahastoa.

\section{Kirjoittajat}

Tiina Saari, YTT, tutkijatohtori,

Tampereen yliopisto,

sähköposti: tiina.saari@tuni.fi

Harri Melin, YTT, professori,

Tampereen yliopisto,

sähköposti: harri.melin@tuni.fi

\section{Kirjallisuus}

Akindinova N., Kuzminov Y. \& Yasin E. (2016) Russia's economy: Before the long transition. Russian Journal of Economics 2 (3), 219-245

Anikin, V. A. (2011) Work in the lives of Russians. Sociological Research 50 (6), 3-16.

Bakker, A. B. \& Demerouti, E. (2016) Job demands-resources theory: taking stock and looking forward. Journal of Occupational Health Psychology 22 (3), 273-285.

Balabanova, B., Rebrov, A. \& Koveshnikov, A. (2018) Managerial styles in privately owned domestic organizations in Russia: Heterogeneity, antecedents, and organizational implications. Management and Organization Review 14 (1), 37-72.

Balabanova, E., Efendiev, A., Ehrnrooth, M. \& Koveshnikov, A. (2015) Idiosyncrasy, heterogeneity and evolution of managerial styles in contemporary Russia. Baltic Journal of Management 10 (1), 2-29.

Balabanova, E., Efendiev, A., Ehrnrooth, M. \& Koveshnikov, A. (2016) Job satisfaction, blat and intentions to leave among blue-collar employees in contemporary Russia. Baltic Journal of Management 11 (1), 21-43.

Best, H. \& Wolf, C. (2015) Logistic Regression. Teoksessa H. Best \& C. Wolf: The Sage handbook of Regression analysis and causal inference. Los Angeles: Sage, 153-172.

Bondarenko, N. (2015) The nature of the current and anticipated shortage of professional skills and qualities of workers in the Russian labor narket. Russian Education and Society 57 (3), 119145.

Cohen, A. \& Golan, R. (2007) Predicting absenteeism and turnover intentions by past absenteeism and work attitudes. Career Development International 12 (5), 416-432.

Demerouti, E., Bakker, A. B., Nachreiner, F. \& Schaufeli, W. B. (2001) The job demands-resources model of burnout. Journal of Applied Psychology 86 (3), 499-512.

Elinkeinoelämän keskusliitto (2018) Venäjä - suuret markkinat, heikko talouskehitys ja pakotteet. [online].<URL:https://ek.fi/mita-teemme/kauppapolitiikka/venaja/>. Luettu 15.10.2018.

Eurofound (2017) Sixth European Working Conditions Survey - Overview report (2017 update), Luxembourg: Publications Office of the European Union. [online]. <URL:https://www.eurofound. europa.eu/publications/report/2016/workingconditions/sixth-european-working-conditionssurvey-overview-report>. Luettu 16.10.2018.

Fischer, R., \& Mansell, A. (2009) Commitment across cultures: A meta-analytical approach. Journal of International Business Studies 40 (8), 1339-1358.

Fey C. F. \& Shekshnia, S. (2011) The key commandments for doing business in Russia. Organizational Dynamics 40 (1), 57-66.

Gallie, D. (2003) The quality of working life: Is Scandinavia different? European Sociological Review 19 (1), 61-79. 
Gimpelson, V. \& Kapeliushnikov, R. (2011) Labor Market Adjustment: Is Russia Different? IZA Discussion Paper No. 5588. Bonn: IZA.

Gimpelson, V. \& Lippoldt, D. (1999) Labour Turnover in Russia: Evidence from the Administrative Reporting of Enterprises in Four Regions. Transition Economics Series No. 4ö Wien: Institute for Advanced Studies.

Gurkov, I. (2014) Management practices in Russian manufacturing subsidiaries of foreign multinational corporations: challenging some beliefs about contemporary Russian industrial management. Post-Communist Economies 26 (2), 220-240.

Gurkov, I. (2016) Human resource management in Russian manufacturing subsidiaries of multinational corporations. Post-Communist Economies 28 (3), 353-372.

Gurvich, E. (2016) Institutional constraints and economic development. Russian Journal of Economics, 2 (4), 349-374.

Hakanen, J. (2005) Työuupumuksesta työn imuun: työhyvinvointitutkimuksen ytimessä ja reunaalueilla. Työ ja ihminen tutkimusraportti 27. Helsinki: Työterveyslaitos.

Hakanen, J., Schaufeli, W. \& Ahola, K. (2008) The Job Demands-Resources model: A three-year crosslagged study of burnout, depression, commitment, and work engagement. Work \& Stress 22 (3), 224-241.

Halbesleben, J. R. B. \& Buckley, M. R. (2004) Burnout in organizational life. Journal of Management 30 (6), 859-79.

Hartikainen, A., Anttila, T., Oinas, T. \& Nätti, J. (2010) Is Finland different? Quality of work among Finnish and European employees. Research on Finnish Society 3, 29-41.

Heininen, P., Mashkina O., Karhunen, P. \& Kosonen, R. (2008) Leningradin lääni yritysten toimintaympäristönä - pk-sektorin näkökulma. Helsingin kauppakorkeakoulun julkaisuja B-88, Helsinki: Helsingin kauppakorkeakoulu.

Jokivuori, P. (2002) Sitoutuminen työorganisaatioon ja ammattijärjestöön - kilpailevia vai täydentäviä? Jyväskylä Studies in Education, Psychology and Social Research 206. Jyväskylä: Jyväskylän yliopisto.

Jokivuori, P. \& Hietala, R. (2007) Määrällisiä tarinoita. Monimuuttujamenetelmien käyttö ja tulkinta. Helsinki: WSOY.

Järvensivu, A., Piirainen, P., Nikkanen, R. \& Viitala, E.
(2011) Työntekijöiden kokema työelämän laatu suomalaisen teollisuuskonsernin Suomen ja Puolan yksiköissä. Työelämän tutkimus 9 (1), 19-36.

Kapeliushnikov, R. \& Oschepkov, A. (2014) The Russian labor market: paradoxes of the postcrisis performance. Working Paper No. WP3/2014/04, Series WP3 Labour Markets in Transition. Moskova: National Research University Higher School of Economics (venäjänkielinen alkuteos).

Karhunen, P., Kosonen, R., Logrén, J. \& Ovaska, K. (2008) Suomalaisyritysten strategiat Venäjän muuttuvassa liiketoimintaympäristössä. Helsingin kauppakorkeakoulun julkaisuja B-84. Helsinki: Helsingin kauppakorkeakoulu.

Kosonen, R. (2008) Henkilösuhteet ja epävirallinen vaikuttaminen venäläisessä liiketoiminnassa. Teoksessa S. Salmenniemi \& A. Rotkirch (toim.) Suhteiden Venäjä. Helsinki: Gaudeamus, 93-121.

Kosonen, R. \& Heliste, P. (2006) Bilateral economic relations between Finland and Russia: Finnish firms' experiences in Northwest Russia. Teoksessa H. Smith (toim.) The two-level game: Russia's relations with Great Britain, Finland and the European Union. Aleksanteri Series 2/2006. Helsinki: Aleksanteri-instituutti, 205-224.

Kosonen, R. \& Parviainen, S. (2010) Viralliset ja epäviralliset käytännöt lyövät kättä venäläisessä liike-elämässä vuonna 2030. Teoksessa O. Kuusi, H. Smith \& P. Tiihonen (toim.) Sopimusten Venäjä 2030. Eduskunnan tulevaisuusvaliokunnan julkaisu 3/2010. Helsinki: Eduskunnan tulevaisuusvaliokunta, 136-160.

Kozina, I. (2010) Transnational corporations, labor relations and trade unions - Russian case. Journal for Labour and Social Affairs in Eastern Europe 13 (1), 69-88.

Leppänen S., Linden M. \& Solanko, l. (2008) Production Uncenrtainty, Enterprises' Social Responsibility and institutional heritage in a Post- Soviet economy. Keskustelun aloitteita \#59. Joensuun yliopisto, taloustieteet.

Lovakov, A. (2016) Antecedents of organizational commitment among faculty: an exploratory study. Tertiary Education and Management 22 (2), 149-170.

Mauno, S. \& Ruokolainen, M. (2008) Organisaatiokulttuurin yhteys henkilöstön työhyvinvointiin ja työasenteisiin. Teoksessa U. Kinnunen, T. Feldt \& S. Mauno (toim.) Työ leipälajina. Jyväskylä: PS-Kustannus, 142-166. 
Melin, H. (1996) Suunnitelman varjossa. Tutkimus yritysjohtajista Neuvostoliitossa ja Venäjällä. Tampere: Tampereen yliopisto.

Melin, H. (2005) Towards New Paternalism in Kondopoga. Teoksessa H. Melin (toim.) Social Structure, Public Space and Civil Society in Karelia. Helsinki: Kikimora Publishers, 61-76.

Mercurio, Z. (2015) Affective commitment as a core essence of organizational commitment. An integrative literature review. Human Resource Development Review 14 (4), 389-414.

Meyer, J. \& Allen, N. (1991) A three-component conceptualization of organizational commitment. Human Resource Management Review 1 (1), 61-89.

Meyer, J., Stanley, D., Herscovitch, L. \& Topolnytsky, L. (2002) Affective, continuance, and normative commitment to the organization: A meta-analysis of antecedents, correlates, and consequences. Journal of Vocational Behavior 61 (1), 20-52.

Meyer, J. P., Stanley, D. J., Jackson, T., McInnis, K., Maltin, E. \& Sheppard L. (2012) Affective, normative, and continuance commitment levels across cultures: a meta-analysis. Journal of Vocational Behavior 80 (2), 225-245.

Michailova, S. \& Worm, V. (2003) Personal networking in Russia and China: blat and guanxi. European Management Journal 21 (4), 509-519.

Mustosmäki, A. (2017) How Bright are the Nordic Lights? Job Quality Trends in Nordic Countries in a Comparative Perspective. Jyväskylä studies in education, psychology and social research 586. Jyväskylä: Jyväskylän yliopisto.

Newman, K. \& Nollen, S. (1996) Culture and congruence: The fit between management practices and national culture. Journal of International Business Studies 27 (4), 753-779.

Ng, T. W. H. \& Feldman, D. C. (2014) Subjective career success: A meta-analytic review. Journal of Vocational Behavior 85 (2), 169 -179.

Palosuo, H. (2000) How good is "normal" health? An exercise in Russian-Finnish comparative survey methodology. Idäntutkimus 7 (3-4), 41-70.

Parent-Thirion, A., Fernández Macías, E., Hurley, J. \& Vermeylen, G. (2007) Fourth European Working Conditions Survey. European Foundation for the Improvement of Living and Working Conditions. Luxembourg: Office for Official Publications of the European Communities.

Puffer, S. \& McCarthy, D. (2011) Two decades of Russian business and management research: An in- stitutional theory perspective. Academy of Management Perspectives 25 (2), 21-36.

Rhoades, L. \& Eisenberg, R. (2002) Perceived organizational support: A report of the literature. Journal of Applied Psychology 87, 698-714.

Riketta, M. (2002) Attitudinal organizational commitment and job performance: a meta-analysis, Journal of Organizational Behavior 23 (3), 257266.

Saari, T. \& Melin, H. (2019) Suomalaiset organisaatiot työnantajina Venäjällä ja Suomessa. Työ- ja elinkeinoministeriö: Työpoliittinen aikakauskirja 62 (2), 39-51.

Saari, T., Melin, H., Balabanova, E. \& Efendiev, A. (2017) The job demands and resources as antecedents for work engagement - Comparative research on Finland and Russia. Baltic Journal of Management 12 (2), 240-254.

Saari, T., Melin, H., Balabanova, E. \& Efendiev, A. (2018) Better leadership, higher work engagement? Comparative study on Finnish and Russian private sector employees. International Journal of Sociology and Social Policy 38 (11/12), 922-943. Saari, T., Sippola, M., Melin, H., Balabanova, E. \& Efendiev, A. (2017) Vertailussa suomalainen ja venäläinen työelämä. Idäntutkimus 24 (1), 20-33.

Seeck, H. (2008) Johtamisopit Suomessa. Taylorismista innovaatioteorioihin. Helsinki: Gaudeamus.

Sippola, M. (2011) Nordic subsidiaries in the Baltic states: Is model transfer possible? Employee Relations 33 (4), 356-374.

Sippola, M. (2016) Dancing to the tune of the employer? Union-management relationships at Nordic subsidiaries in Russia. Economic and Industrial Democracy. [online]. <URL:https://journals.sagepub.com/doi/ full/10.1177/0143831X16669841>. Luettu 16.10.2018.

Suomalais-venäläinen kauppakamari (2018) Suomen ja Venäjän välinen kauppa. [online]. <URL:https://www.svkk.fi/suomen-ja-venajanvalinen-kauppa/>. Luettu 15.10.2018.

Sutela, H. \& Lehto, A-M. (2013) Työolojen muutokset 1977-2013. Helsinki: Tilastokeskus.

Tabachnick, B. \& Fidell, L. (2001) Using multivariate statistics. Fourth edition. Boston: Allyn and Bacon.

Tan, H., Savchenko, Y., Gimpelson, V., Kapelyushnikov, R. \& Lukyanova, A. (2007) Skills shortages and training in Russian enterprises. IZA Discussion Paper No. 2751. Bonn: IZA. 
Transparency International (2018) Corruption Perceptions Index 2017. [online]. <URL:https:// www.transparency.org/news/feature/corruption_perceptions_index_2017>. Luettu 2.4.2019.

Turunen, T. (2012) Työorientaatiot muutoksessa? Suomalaisten palkansaajien työhön ja organisaatioon sitoutuminen sekä työhön kohdistuvat odo- tukset eurooppalaisessa vertailussa. Sosiaalitieteiden laitoksen julkaisuja 2012:4. Helsinki: Helsingin yliopisto.

Wasti, S. A. (2003) Organizational commitment, turnover intentions and the influence of cultural values. Journal of Occupational and Organizational Psychology 76 (3), 303-321.

\section{Liitteet:}

Liitetaulukko 1: Analyysissä käytetyt muuttujat

\begin{tabular}{|c|c|c|c|}
\hline Muuttuja & Kysymykset & Vastaus-vaihtoehdot & $\begin{array}{l}\text { Summa- } \\
\text { muuttujan } \\
\text { alpha }\end{array}$ \\
\hline $\begin{array}{l}\text { Affektiivinen } \\
\text { sitoutuminen }\end{array}$ & $\begin{array}{l}\text { 1) Koen työpaikkani ongelmien olevan myös mi- } \\
\text { nun ongelmiani, 2) Tunnen olevani kuin "osa per- } \\
\text { hettä" tässä työpaikassa, 3) Työskentelyllä juuri } \\
\text { tässä organisaatiossa on minulle suuri henkilö- } \\
\text { kohtainen merkitys. }\end{array}$ & $\begin{array}{l}1 \text { täysin samaa mieltä... } \\
5 \text { täysin eri mieltä. }\end{array}$ & $\begin{array}{l}\text { Suomi } 0,661 \\
\text { Venäjä } 0,719\end{array}$ \\
\hline $\begin{array}{l}\text { Jatkuvuus- } \\
\text { sitoutuminen }\end{array}$ & $\begin{array}{l}\text { 1) Tästä työpaikasta lähteminen vaikuttaisi huo- } \\
\text { nolla tavalla liian moneen asiaan elämässäni, } \\
\text { 2) Minulla ei ole juurikaan sellaisia vaihtoehtoja, } \\
\text { jotka saisivat harkitsemaan työpaikan vaihtamista, } \\
\text { 3) Jos en olisi jo uhrannut niin paljon tälle työpai- } \\
\text { kalle, voisin harkita vaihtavani työpaikkaa. }\end{array}$ & $\begin{array}{l}1 \text { täysin samaa mieltä... } \\
5 \text { täysin eri mieltä. }\end{array}$ & $\begin{array}{l}\text { Suomi } 0,595 \\
\text { Venäjä } 0,694\end{array}$ \\
\hline $\begin{array}{l}\text { Normatiivinen } \\
\text { sitoutuminen }\end{array}$ & $\begin{array}{l}\text { 1) Tunnen että minulla on velvollisuus pysyä ny- } \\
\text { kyisen työnantajani palveluksessa, 2) Vaikka se } \\
\text { olisikin oman etuni mukaista, tästä työpaikasta } \\
\text { lähteminen nyt ei tuntuisi oikealta, 3) Tuntisin } \\
\text { syyllisyyttä jos vaihtaisin nyt työpaikkaa. }\end{array}$ & $\begin{array}{l}1 \text { täysin samaa mieltä... } \\
5 \text { täysin eri mieltä. }\end{array}$ & $\begin{array}{l}\text { Suomi } 0,853 \\
\text { Venäjä } 0,791\end{array}$ \\
\hline $\begin{array}{l}\text { Tyytyväisyys } \\
\text { Johtamiseen }\end{array}$ & $\begin{array}{l}\text { 1)Esimieheni tukee ja rohkaisee minua, } \\
\text { 2)Esimieheni antaa kiitosta hyvistä työsuorituk- } \\
\text { sista, 3) Esimieheni on innostava, } \\
\text { 4) Esimieheni luottaa työntekijöihinsä }\end{array}$ & $\begin{array}{l}1 \text { täysin samaa mieltä... } \\
5 \text { täysin eri mieltä. }\end{array}$ & $\begin{array}{l}\text { Suomi } 0,911 \\
\text { Venäjä } 0,924\end{array}$ \\
\hline $\begin{array}{l}\text { Vaikutus- } \\
\text { mahdollisuudet }\end{array}$ & $\begin{array}{l}\text { Kuinka paljon voitte vaikuttaa seuraaviin asioihin: } \\
\text { 1) Siihen, missä järjestyksessä teette työnne? } \\
\text { 2) Työtahtiinne? 3) Työaikoihinne? } \\
\text { 4) Työmäärään? }\end{array}$ & $\begin{array}{l}1 \text { paljon, } 2 \text { melko paljon, } \\
3 \text { melko vähän, } 4 \text { en lain- } \\
\text { kaan. }\end{array}$ & $\begin{array}{l}\text { Suomi } 0,817 \\
\text { Venäjä } 0,799\end{array}$ \\
\hline Työyhteisön tuki & $\begin{array}{l}\text { 1) Työpaikallamme vallitsee avoin ilmapiiri ja } \\
\text { hyvä yhteishenki, 2) Saatteko tukea ja rohkaisua } \\
\text { työtovereiltanne kun työ tuntuu hankalalta? 3) } \\
\text { Koetteko olevanne työyhteisön arvostettu jäsen? }\end{array}$ & $\begin{array}{l}1 \text { täysin samaa mieltä... } \\
5 \text { täysin eri mieltä. }\end{array}$ & $\begin{array}{l}\text { Suomi } 0,864 \\
\text { Venäjä } 0,877\end{array}$ \\
\hline $\begin{array}{l}\text { Kehittymis- } \\
\text { mahdollisuudet }\end{array}$ & $\begin{array}{l}\text { Mahdollisuudet kehittää itseäni nykyisessä työ- } \\
\text { paikassani ovat... }\end{array}$ & $\begin{array}{l}1 \text { hyvät, } 2 \text { kohtalaiset, } \\
3 \text { huonot }\end{array}$ & \\
\hline $\begin{array}{l}\text { Palkan oikeuden- } \\
\text { mukaisuus }\end{array}$ & $\begin{array}{l}\text { Onko saamanne palkka mielestänne oikeudenmu- } \\
\text { kainen, jos sitä vertaa muissa ammateissa makset- } \\
\text { tuihin palkkoihin? }\end{array}$ & \multicolumn{2}{|c|}{$\begin{array}{l}\text { Palkkani on 1...selvästi korkeampi kuin pi- } \\
\text { täisi olla 2...hieman korkeampi kuin pitäisi } \\
\text { olla 3...suunnilleen oikea } 4 \text {...hieman mata- } \\
\text { lampi kuin pitäisi olla } 5 . . . \text { selvästi matalamp } \\
\text { kuin pitäisi. }\end{array}$} \\
\hline
\end{tabular}


Liitetaulukko 2. Korrelaatiot / Suomi

\begin{tabular}{|l|l|l|l|l|l|l|l|l|l|}
\hline Suomi & 1. & 2. & 3. & 4. & 5. & 6. & 7. & 8. & 9. \\
\hline 1. Affektiivinen sitoutuminen & 1 & & & & & & & & \\
\hline 2. Johtaminen &, $324^{* *}$ & 1 & & & & & & & \\
\hline 3. Kehittymis-mahdollisuudet &, $475^{* *}$ &, $446^{* *}$ & 1 & & & & & & \\
\hline 4. Vaikutusmahdollisuudet &, $311^{* *}$ &, $224^{* *}$ &, $344^{* *}$ & 1 & & & & & \\
\hline 5. Työyhteisön tuki &, $479^{* *}$ &, $539^{* *}$ &, $362^{* *}$ &, $180^{* *}$ & 1 & & & & \\
\hline 6. Palkan oikeudenmukaisuus &, $207^{* *}$ &, $121^{*}$ &, $338^{* *}$ &, $318^{* *}$ &, $118^{*}$ & 1 & & & \\
\hline 7. Ikä & $-0,033$ & $-0,078$ & $-0,051$ & 0,091 &,$- 111^{*}$ & 0,067 & 1 & & \\
\hline 8. Sukupuoli &,$- 140^{*}$ & $-0,072$ &,$- 122^{*}$ & $-0,029$ &,$- 145^{* *}$ & 0,014 &, $114^{*}$ & 1 & \\
\hline 9. Työvuodet organisaatiossa &,$- 121^{*}$ & $-0,088$ &,$- 111^{*}$ & $-0,074$ &,$- 141^{*}$ & 0,037 &, $706^{* *}$ & 0,073 & 1 \\
\hline
\end{tabular}

Liitetaulukko 3. Korrelaatiot / Venäjä

\begin{tabular}{|l|l|l|l|l|l|l|l|l|l|l|}
\hline Venäjä & 1. & 2. & 3. & 4. & 5. & 6. & 7. & 8. & 9. \\
\hline 1. Affektiivinen sitoutuminen & 1 & & & & & & & & \\
\hline 2. Johtaminen &, $347^{* *}$ & 1 & & & & & & & \\
\hline 3. Kehittymis-mahdollisuudet &, $371^{* *}$ &, $316^{* *}$ & 1 & & & & & & \\
\hline 4. Vaikutus-mahdollisuudet &, $186^{* *}$ &, $207^{* *}$ &, $213^{* *}$ & 1 & & & & & \\
\hline 5. Työyhteisön tuki &, $525^{* *}$ &, $595^{* *}$ &, $368^{* *}$ &, $246^{* *}$ & 1 & & & & \\
\hline 6. Palkan oikeudenmukaisuus &, $167^{* *}$ &, $194^{* *}$ &, $162^{* *}$ & 0,111 &, $166^{* *}$ & 1 & & & \\
\hline 7. Ikä &, $196^{* *}$ & 0,038 &, $142^{*}$ & 0,043 & 0,115 & 0,042 & 1 & & \\
\hline 8. Sukupuoli & $-0,055$ & $-0,028$ & 0,063 & 0,068 & $-0,087$ & $-0,050$ & $-0,072$ & 1 & \\
\hline 9. Työvuodet organisaatiossa &, $166^{* *}$ & 0,033 & 0,043 & 0,083 &, $158^{*}$ & 0,079 &, $419^{* *}$ & $-0,090$ & 1 \\
\hline
\end{tabular}

